\title{
Surgical smoke generated by electrocautery
}

\author{
Tamara Searle $^{1} \cdot$ Faisal R. Ali $^{2,3} \cdot$ Firas Al-Niaimi $^{4}$ (D) \\ Received: 14 August 2020 / Accepted: 22 November 2020 / Published online: 9 January 2021 \\ (C) Springer-Verlag London Ltd., part of Springer Nature 2021
}

\section{Dear Professor Nouri,}

We welcome the timely and pragmatic British Medical Laser Association guidance regarding measures needed to resume laser services following COVID-19 lockdown and commend the author for his comprehensive work [1]. Many clinics using laser devices also commonly use electrocautery when undertaking dermatologic surgery which likewise can generate plumes ("surgical smoke"). These plumes are potentially infectious, toxic, and carcinogenic [2]. Surgical plume has been found to harbor particulate pathogens such as coagulase-negative staphylococci, Corynebacterium and Neisseria [3], as well as human papillomavirus [4]. Although there are no reported cases of COVID-19 transmission through the electrocautery plume, the minute size of the particles [5], their high transmissibility [6], and the fact that they have been found in a variety of bodily fluids (including blood, peritoneal fluid [7], and feces [8]) increase the plausibility of finding COVID-19 particles in plumes generated by electrocautery devices $[9,10]$. The author suggested use of smoke evacuation devices with various filter devices available [1]. These include charcoal filters (capable of absorbing gas and vapor), high efficiency particulate air filters (filtering particles of greater than $0.3 \mu \mathrm{m}$ with an efficiency of $99.97 \%$ ), and ultralow particular air filters (ULPA) (filtering particles of greater than $0.1 \mu \mathrm{m}$ with an efficiency of $99.99 \%$ ). A combination of ULPA and charcoal filters is the most effective filtration method [11]. In addition to adopting many of the measures suggested by the author for laser devices [1], including use of personal protective equipment and smoke evacuation

Firas Al-Niaimi

firas55@hotmail.com

1 University of Birmingham Medical School, Birmingham, UK

2 Guy's and St Thomas' NHS Foundation Trust, St John's Institute of Dermatology, London, UK

3 Vernova Healthcare CIC, Cheshire, UK

4 Department of Dermatology, Aalborg University Hospital, Aalborg, Denmark devices, practitioners using electrocautery in their clinics may also wish to consider the use of bipolar (rather than unipolar) devices and lower energy settings when using electrocautery devices, both of which are associated with reduced generation of plumes [1].

\section{Compliance with ethical standards}

Conflict of interest The authors declare that they have no conflict of interest.

Consent for publication All authors have approved this final submitted version of the manuscript and consent to its submission for consideration of publication.

\section{References}

1. Madan V (2020) Resumption of laser/IPL skin services post COVID-19 lockdown-British Medical Laser Association (BMLA) guidance document. Lasers Med Sci 27:1-5. https://doi.org/10. 1007/s10103-020-03086-Z

2. Searle T, Ali FR, Al-Niaimi F (2020) Surgical plume in dermatology: an insidious and often overlooked hazard. Clin Exp Dermatol. https://doi.org/10.1111/ced.14350

3. Capizzi PJ, Clay RP, Battey MJ (1998) Microbiologic activity in laser resurfacing plume and debris. Lasers Surg Med 23(3):172174

4. Sawchuk WS, Weber PJ, Lowy DR, Dzubow LM (1989) Infectious papillomavirus in the vapor of warts treated with carbon dioxide laser or electrocoagulation: detection and protection. J Am Acad Dermatol 21(1):41-49

5. Leung NHL, Chu DKW, Shiu EYC et al (2020) Respiratory virus shedding in exhaled breath and efficacy of face masks. Nat Med 20: 676-680

6. Chen N, Zhou M, Dong X et al (2020) Epidemiological and clinical characteristics of 99 cases of 2019 novel coronavirus pneumonia in Wuhan, China: a descriptive study. Lancet. 395:507-513

7. Coccolini F, Tartaglia D, Puglisi A et al (2020) SARS-CoV-2 is present in peritoneal fluid in COVID-19 patients. Ann Surg. Available at: https://journals.lww.com/annalsofsurgery/ Documents/SARS-CoV-2 is present in peritoneal fluid in COVID-19 patients.pdf (accessed 14 August 2020)

8. Wu Y, Guo C, Tang L et al (2020) Prolonged presence of SARS-CoV2 viral RNA in faecal samples. Lancet Gastroenterol 5:434-435 
9. Mowbray NG, Ansell J, Horwood J et al (2020) Safe management of surgical smoke in the age of COVID-19. Br J Surg 107(11): $1406-1413$

10. Mintz Y, Arezzo A, Boni L et al (2020) The risk of COVID-19 transmission by laparoscopic smoke may be lower than for laparotomy: a narrative review. Surg Endosc 34(8):3298-3305
11. Katoch S, Mysore V (2019) Surgical smoke in dermatology: its hazards and management. J Cutan Aesthet Surg 12(1):1-7

Publisher's note Springer Nature remains neutral with regard to jurisdictional claims in published maps and institutional affiliations. 